\title{
Study on Children Product Design and Development Based on Fashion Consumption \\ Liming Zhang ${ }^{1}$ \\ ${ }^{1}$ Qujing normal college, yunnan qujing city kirin sanjiang avenue, 655011
}

Keywords: Fashion consumption; Children's product development and design

\begin{abstract}
With the pursuit of fashionable product ,people are spending more money on their children. The consuming proportion for children is increasingly higher for children in a family. To meet the need of the children, when designing products for children, one should consider not only the character of the children, but fashion as well. In this thesis, after analyzing the fashion consumption and the problems in the children product design , some measures are being given.

With the development of social economy and the improvement of consumption level, people's consumption concept has changed from the demand for products to the pursuit of quality. The full liberalization of the country's two child policy increases the demand for children's products. Children have the characteristics of liveliness, imitation, imagination and thirst for knowledge. Many enterprises focus on children's needs as the basic starting point for product research and development. Under the concept of fashion consumption, fashion factors in children's product design are often neglected. Enterprises should seize the favorable market opportunities, meet the needs of children, to achieve profit growth, it must be in fashion consumption trend of production is in line with the children's consumption demand characteristics, and follow the fashion trend of children's products.
\end{abstract}

\section{First. fashion consumption}

The current consumer market, in the premise of meeting the basic needs of the consumer, pay attention to the integration of fashion elements and products, fashion consumption has become a popular trend in the consumer market. "Fashion consumption" refers to the consumption behavior and lifestyle of individuals seeking the sense of belonging and individual identity through the pursuit of fashion consumption." [1] with the induction of fashion consumption, shopping malls in the flourish of commodity Street brand; a superb collection of beautiful things very tempting, media images and provocative advertisements are to attract the attention of consumers, stimulate their desire to purchase, fashion consumption is not a simple commodity use value of consumption, but the consumer personality, role identity, and status symbol.

\section{Two. Problems of children's products}

\section{Adult}

In recent years, children's products have been blended with fashion, personality, taste and other elements, showing individuality and popularity, but there is an adult problem in children's products such as toys, clothing, furniture, books and so on. Such as adult children's clothing: adult style, single color, reflecting tight tailoring effect, especially the use of a large number of rivets, beads, chains and other complex decorative elements, resulting in potential safety problems, is not conducive to children's health. Adult advertising: let children speak for razors, cars and other products, children's behavior in advertising does not conform to the behavior characteristics of children's actual age. In the process of children's growth, they are happy, healthy and simple, while enterprises overemphasize the product of adult, affecting the formation of children's values and consumption concept.2. Homogenization

In the product of children, many similar products have similar problems in material selection, design, modeling, function, business model and so on. Homogenization is the same kind of products in the structure, function, style, service, price, quality, technical basis and other aspects have a great similarity, and there is a strong substitutability." [2], such as children's books, theme parks, experiential children's goods, daily necessities homogenization, etc., and the same pattern of business, imitation, plagiarism, lack of creativity and so on. Product homogeneity makes children lose freshness to the product, appear 
aesthetic fatigue, unable to stimulate desire; for enterprises, aggravate market competition, leading to low brand recognition, disrupt the normal market order.

\section{Low standardization}

Product quality is directly related to children's quality of life and physical and mental health. The relevant state departments and industries have formulated regulations and regulations, such as the national toy safety technical specifications, the national compulsory standards for children's toys, and the requirements for child safety in product standards. However, behind the hot market of children's products, it presents an embarrassing situation, that is, product quality problems are forbidden repeatedly. "In May 2017, the implementation of the national total of children's products recall 70 times, involving the bassinet, children's stationery, children with plastic products and other products, a total of 25 thousand and 500 pieces of ${ }^{[3]}$ children's products quality and low business sad standardization requirements inseparable. Because businesses in the interests of the trend, will reduce production standards, in order to damage the legitimate rights and interests of consumers at the cost of achieving the purpose of enterprises.

\section{High price}

Children's consumption behavior begins to change from beauty to luxury. Some parents are vanity, the Joneses are popular, too superstitious foreign goods, when buying products, high prices become the focus of attention, and reduce the product quality, safety, comfort and other factors concern. Enterprises in order to cater to this kind of parental consumer psychology, the children's food and daily necessities are labeled "children exclusive" label, such as children, children, children's soy sauce noodles washing machine and so on, the price is much higher than similar ordinary products, but the product function difference is small, not up to the expectations of consumers effect, but also easy to make the children have psychological comparisons.

\section{Three. Development and design of children's products under fashion consumption}

\section{The introduction of green design concept}

With the demand for children's products from the traditional practicality, aesthetics to ductility, safety, environmental protection, enterprises will introduce green design concept into the product. Green design is a design method based on the consciousness of ecological environment, in order to meet the function, quality, life and cost of the product, to the environment attributes, resource property and energy property priority in the product lifecycle." ${ }^{4]}$

Under the influence of fashion consumption concept, green design is a natural, ecological and extensible design method. First of all, the choice of materials. Materials should have the function of environmental protection and recycling, prohibit the use of toxic substances such as formaldehyde, inferior plastic and other materials to ensure children's health. Followed by the design link. Other products such as removable and adjustable function, stimulate children's imagination; product versatility to prolong the service life of the products, to avoid a single function to speed up the products eliminated and discarded; green packaging products, packaging materials should be green, environmental protection and recycling of the ecological material used. Third is the production process. Strengthen the management and control of product production process, including good production environment, standardization of production process, safety and hygiene of production, audit product quality parameters, etc..

\section{The display of simple style}

Too loud and complicated product design can cause people's aesthetic fatigue. Children's product design should adopt a flexible and simple style, and cultivate children's aesthetic consciousness. Simple design mainly grasp two points, one is humanized design. Products should pay attention to comfort, convenience, safety, etc., more attention should be paid to detail design, actual demand, production costs, adhere to the people-oriented design concept, in line with the law of children's growth and ensure physical and mental health. The two is natural simplicity design. The raw materials to reflect the natural characteristics; design to draw inspiration from nature, such as simplified design and bionic design, the design is simple, easy to operate, let the children have a sense of return to nature in use, the organic 
integration of man and nature embodied.

\section{Representation of creative needs}

Children's product design should be based on its actual needs, with new shapes, unique appearance and so on to attract children. Some enterprises are keen on imitation, resulting in a single product form, innovation is not enough. Product creativity is the trend of society under fashion consumption. Interesting. Children have the characteristics of moving, attention is not easy to concentrate, in the design of product function, shape, appearance and interesting combination of organic, causing children to pay attention to and find fun. Such as intelligence. Emphasis on intelligence is based on the needs of children's intellectual development in different stages, on the basis of consumption, entertainment, enhance interactive experience, intellectual development, to achieve the brain and hand together with the puzzle effect. Such as creativity. Product design should reflect creativity and imagination, promote the activity of children's thinking, and cultivate their image thinking and creative thinking ability.

\section{The application of personalized color}

Color is the most effective visual transmission elements of the product, children have a special sensitivity to color, can stimulate children's desire to buy, stimulate emotion, enhance imagination. Personalized color design is aimed at children groups, combined with its unique consumer psychology and color psychology for color design. First, color palette, children's products should Nuanshaidiao collocation of bright colors and high saturation can cause children's emotional satisfaction and pleasure, and gray tone to children psychologically depressed, easy to cause the weak and timid mentality. Secondly, attention should be paid to color matching. The color will play a role in attracting attention and arouse the interest of the. Complex color matching is not conducive to children's identification and memory products, but will cause confusion in children's thinking and cognition, anxiety and irritability. Finally, to combine with personalized modeling design, improve product interest, let the children really fall in love with the product.

\section{Design for Sustainability}

Sustainable design is in the design of integrated technology, economic, environmental and social factors, innovative design, to guide and meet consumer demand, a design method of "so that direct and indirect stakeholders of the long-term benefit of ${ }^{[5]}$ children at present in the market in a single storage function of the product life cycle is short, the problem the sustainability of the poor, to extend the product life cycle, it must be sustainable design. First, the choice of materials reflects ecology. The choice of materials should follow the concept of sustainable development, choose green, environmental protection and recyclable resources, so that products become green products. Secondly, the combination of multi function and sustainability. Children grow faster, some products use cycle is short, parents have to change products frequently, resulting in waste of resources. The design focuses on the reorganization of product structure, the embodiment of multi-functional, and can realize the sustainability of the product. Third, strengthen the interesting and intelligent design. Advocate participatory concept, stimulate interest, meet their needs for fun, and enhance the interaction between children and parents, and actively cultivate children's hands-on and practical ability of brain and mind, which is conducive to the development of children's intelligence.

Epilogue

With the optimization of people's quality of life, the influence of fashion consumption concept, the parents as the consumer leader pay more and more attention to children's products. Children's products for children should meet the physical and psychological needs, enterprises should take children's consumer oriented, fashion consumption concept into the product design, and actively promote the green design, style design, color design, personalized needs of creative design and sustainable design, make the products in line with the current fashion trends, to meet consumer demand. Give children more comfortable shopping experience.

\section{Acknowledgements}

Fund project: qujing normal college teaching reform project (JGXM2016016)

Author introduction: Cui Limei (1980.12 -), female, han ethnic group, yunnan xuanwei, master, lecturer, 
main research direction for management science and engineering.

\section{Reference}

[1] Tian Lei. Research on fashion consumption and identity [D]. Sichuan Academy of Social Sciences, 2012.

[2] our study. Journal of homogenization of product semiotics in Changzhou Institute of [J]. based on 2005,18 (1): 72-75.

[3] AQSIQ released information on recall of children's goods [J]. Fujian quality and technical supervision, 2017.

[4] Jiang Manqun. The concept of green design research and application in the design of children's products in the $[\mathrm{J}]$. design, 2017:14-16

[5] Ma Yuming. Explore sustainable design for product life cycle design [J]., 2017:120-121 